JURNAL PENDIDIKAN, p-ISSN 2715-095X, e-ISSN 2686-5041

Volume 29, No.3, Nopember 2020 (231-240)

Online: http://journal.univetbantara.ac.id/index.php/jp

\title{
Meningkatkan Hasil Belajar Handstand dalam Pembelajaran Penjasorkes Melalui Media Audio Visual Pada Siswa Kelas XI MM2 SMK N 1 Miri Kabupaten Sragen Semester 1 Tahun Pelajaran 2019/2020
}

\author{
Kusmiyati \\ Guru Penjasorkes SMKN 1 Miri, Sragen, email: kusmiyatimiya1@gmail.com
}

\begin{abstract}
Abstrak: Handstand merupakan salah satu materi senam lantai yang diajarkan di sekolah Menengah Kejuruan. Akan tetapi, kenyataannya dalam proses pembelajaran belum terlaksana secara optimal dikarenakan siswa kurang jelas dalam menerima materi dari guru, dan merasa contoh gerakan yang diberikan terlalu cepat sehingga siswa kesulitan dalam memahami materi. Data dari pengamatan psikomotor diperoleh hasil pada waktu setelah perlakuan mencapai 75\% (cukup baik). Data hasil pengamatan afektif pada waktu setelah perlakuan mencapai 77\% (cukup baik) pada siklus II mengalami peningkatan mencapai 84\% (baik), setelah dianalisis dengan rumus Hake's Normalized Gain dan mengalami peningkatan sebesar 0,3 dengan kriteria sedang. Dari hasil pemahaman siswa (kognitif) pada siklus I mencapai $79 \%$ (kualifikasi cukup) pada siklus II mengalami peningkatan mencapai $87 \% \%$ (baik), setelah dianalisis dengan rumus Hake's Normalized Gain dan mengalami peningkatan sebesar 0,3 dengan kriteria sedang. Berdasarkan dari hasil penelitian diatas, disimpulkan bahwa pembelajaran dengan menggunakan media audio visual dapat meningkatkan hasil belajar handstand siswa. Oleh karena itu diharapkan bagi guru penjasorkes di SMK Negeri 1 Miri dapat menggunakan media audio visual dalam pembelajaran handstand. Pembelajaran dengan mengunakan media audio visual juga dapat dijadikan alternatif sistem pengajaran agar suasana pembelajaran selalu menyenangkan sesuai tujuan dalam pembelajaran Paikem.
\end{abstract}

Kata-kata Kunci: Media, Audio Visual, pembelajaran.

\section{Improving Handstand Learning Outcomes in Physical Education Learning Through Audio Visual Media for Class XI MM2 Students of SMK N 1 Miri Sragen Regency Semester 1 Academic Year 2019/2020}

\author{
Kusmiyati \\ Physical Education Teacher at SMKN 1 Miri, Sragen,email: kusmiyatimiya1@gmail.com
}

\begin{abstract}
Handstand is one of the floor exercise materials taught in Vocational High Schools. However, the reality is that the learning process has not been carried out optimally because students are not clear in receiving the material from the teacher, and feel the examples of movements given are too fast so that students have difficulty understanding the material. Data from psychomotor observations obtained results at the time after treatment reached $75 \%$ (good enough). Affective observation data at the time after treatment reached $77 \%$ (good enough) in cycle II increased to $84 \%$ (good), after being analyzed with the formula of Hake's Normalized Gain and an increase of 0.3 with moderate criteria. From the results of students' understanding (cognitive) in cycle I reached 79\% (sufficient qualification) in cycle II experienced an increase of $87 \% \%$ (good), after being analyzed by the formula of Hake's Normalized Gain and an
\end{abstract}


increase of 0.3 with moderate Based on the results of the above research, it was concluded that learning using audio-visual media could improve student handstand learning outcomes. Therefore, it is hoped that physical education teachers at SMK Negeri 1 Miri can use audiovisual media in handstand learning. Learning by using audio-visual media can also be used as an alternative learning system so that the learning atmosphere is always enjoyable according to the objectives of Paikem learning.

Keywords: Media, Audio Visual, learning.

\section{Pendahuluan}

Pendidikan jasmani, olahraga dan kesehatan yang diajarkan di sekolah memiliki peranan yang sangat penting yaitu memberikan kesempatan kepada peserta didik untuk terlibat langsung dalam berbagai pengalaman dalam belajar melalui aktivitas jasmani yang dilakukan secara sistematis. Pembekalan pengalaman belajar ini diarahkan untuk membina pertumbuhan fisik sekaligus pembentukan pola hidup sehat sepanjang hayat. Upaya untuk mewujudkan tujuan penjasorkes dapat dilakukan dengan menggunakan metode, model dan pendekatan yang sesuai dengan kondisi sekolah yang bersangkutan. Akan tetapi, yang menjadi permasalahan ialah metode atau pendekatan dalam mengajar penjas di sekolah yang masih monoton sehingga pembelajaran menjadi tidak menarik dan siswa kurang termotivasi untuk mengikuti pembelajaran. Senam ketangkasan merupakan salah satu materi yang diajarkan di SMK Negeri 1 Miri. Hal tersebut sesuai dengan standar kompetensi dan kompetensi dasar yang terdapat pada silabus penjasorkes kelas XI MM 2 semester 1 di SMK tersebut. Salah satu materi senam ketangkasan yang diajarkan di sekolah tersebut ialah pembelajaran hanstand. Handstand merupakan salah satu materi senam yang penguasaan rangkaian keterampilan geraknya dilakukan secara berurutan. Hal ini dikarenakan siswa yang kurang bisa menangkap dengan jelas penjelasan dan contoh yang diberikan oleh guru, sehingga pada saat melakukan masih mengalami kesulitan. Salah satu upaya dalam mengatasi kesulitan tersebut ialah dengan memberikan materi dengan bentuk audio visual dengan tujuan siswa dapat melihat dan mengamati gerak "handstand" yang sudah dimodifikasi agar siswa mudah dalam memahami setiap gerakan yang dilakukan. Tampilan audio visual ini dikemas dalam bentuk yang sederhana supaya siswa dapat benar-benar memperhatikan urutan, cara pemanasan, awalan, posisi handstand dan pendaratan yang benar.

Berdasarkan latar belakang tersebut, maka permasalahan dalam penulisan ini dirumuskan sebagai berikut "Apakah pembelajaran handstand menggunakan media audio visual dapat meningkatkan hasil belajar handstand siswa kelas XI SMK Negeri 1 Miri Kabupaten Sragen Tahun Pelajaran 2019/2020?" Sesuai dengan permasalahan tersebut di atas, maka tujuan dalam penelitian ini adalah untuk mengetahui efektifitas pembelajaran hasndstand menggunakan media audio visual dalam meningkatkan hasil belajar guling depan siswa kelas XI SMK Negeri 1 Miri Kabupten Sragen Tahun Pelajaran 2019/2020. Pendidikan jasmani adalah suatu proses pembelajaran melalui aktivitas jasmani yang didesain untuk meningkatkan kebugaran jasmani, mengembangkan keterampilan motorik, pengetahuan dan perilaku hidup sehat dan aktif, sikap sportif, dan kecerdasan emosi. Lingkungan belajar diatur secara saksama untuk meningkatkan pertumbuhan dan 
perkembangan seluruh ranah jasmani, psikomotor, kognitif, dan afektif setiap siswa (Samsudin, 2008:2). Secara umum tujuan pendidikan jasmani dapat diklasifikasikan ke dalam empat katagori, yaitu : 1)Perkembangan fisik. Tujuan ini berhubungan dengan kemampuan melakukan aktivitas-aktivitas yang melibatkan kekuatan kekuatan fisik dari berbagai organ tubuh seseorang (physical fitness). 2)Perkembangan gerak. Tujuan ini berhubungan dengan kemampuan gerak secara efektif, efisien, halus, indah, sempurna (skillful). 3) Perkembangan mental. Tujuan ini berhubungan dengan kemampuan berpikir dan mengintrepretasikan keseluruhan pengetahuan tentang pendidikan jasmani ke dalam lingkungannya sehingga memungkinkan tumbuh dan berkembangnya pengetahuan, sikap, dan tanggung jawab siswa. 4) Perkembangan sosial. Tujuan ini berhubungan dengan kemampuan siswa dalam menyesuaikan diri pada suatu kelompok atau masyarakat (Adang Suherman, 2000: 22-23). Ruang lingkup mata pelajaran Penjasorkes menurut Sumanto Y (1992: 13) meliputi beberapa aspek, antara lain yaitu permainan dan olahraga (meliputi: olahraga tradisional, permainan eksplorasi gerak, keterampilan lokomotor non lokomotor dan manipulatif, atletik, kasti, rounders, kippers, sepakbola, bolabasket, bolavoli, tenismeja, tenis lapangan, bulu tangkis, dan bela diri serta aktivitas lainnya; Aktivitas pengembangan (meliputi mekanika sikap tubuh, dan komponen kebugaran jasmani dan bentuk postur tubuh serta aktivitas lainnya; Ativitas senam (meliputi: ketangkasan sederhana, ketangkasan tanpa alat, ketangkasan dengan alat dan senam lantai serta aktivitas lainnya; Aktivitas ritmik (meliputi: gerak bebas, senam pagi, SKJ, senam aerobic serta aktivitas lainnya; Aktivitas air (meliputi: permainan di air, keselamatan air, keterampilan bergerak di air, dan renang serta aktivitas lainnya; Pendidikan luar kelas (meliputi: piknik/karyawisata, pengenalan lingkungan, berkemah, menjelajah dan mendaki gunung; Kesehatan (meliputi: penanaman budaya hidup sehat dalam kehidupan sehari-hari khususnya yang terkait dengan perawatan tubuh agar tetap sehat, merawat lingkungan yang sehat, memilih makanan dan minuman yang sehat, merawat lingkungan yang sehat, memilih makanan dan minuman yang sehat, mencegah dan merawat cidera, mengatur waktu istirahat yang tepat dan berperan aktif dalam kegiatan P3K dan UKS, aspek kesehatan merupakan aspek tersendiri dan secara implisit masuk kedalam semua aspek.

Schmidth (1991) yang dikutip Amung ma'mun (2000:45) menjelaskan bahwa "belajar gerak ialah suatu rangkaian proses yang berhubungan dengan latihan atau pengalaman yang mengarah pada terjadinya perubahan yang relatif permanen dalam kemampuan seseorang untuk menampilkan gerakan-gerakan yang terampil". Berdasarkan pendapat Schmidth tersebut, maka terdapat tiga hal pokok dalam belajar gerak yaitu meliputi: 1) belajar merupakan proses yang di dalamnya terjadi pemberian latihan atau pengalaman, 2) belajar tidak langsung teramati, 3) perubahan yang terjadi relatif permanen. Peningkatan kemampuan gerak bisa diidentifikasikan dalam bentuk: 1) gerakan bisa dilakukan dengan mekanika tubuh yang makin efisien, 2) gerakan bisa dilakukan semakin lancar dan terkontrol, 3) pola atau bentuk gerakan semakin bervariasi, dan 4) gerakan semakin bertenaga (Sugiyanto, 1993: 119). Untuk mencapai perubahan atau peningkatan pada diri siswa, maka dalam proses pembelajaran harus ditetapkan prinsip-prinsip pembelajaran yang tepat. Menurut Dimyati dan Mudjiono (2009:42) menjelaskan bahwa, " Prinsip-prinsip pembelajaran meliputi perhatian dan motivasi, keaktifan siswa, keterlibatan langsung, pengulangan, tantangan, balikan dan penguatan serta perbedaan individual ". 
Handstand merupakan salah satu materi senam yang penguasaan rangkaian keterampilan geraknya dilakukan secara berurutan. Biasworo Adisuyanto (2009: 100-101) berpendapat bahwa keterampilan gerak handstand diperoleh dari berbagai gerak awalan. Beberapa awalan yang dapat menunjang terjadinya gerak akhir handstand bisa diperoleh dari:

Sikap awalan jongkok; Pelaksanaan keterampilan gerak handstand dapat diawali dari sikap jongkok dengan kaki rapat. Diawali dari sikap jongkok, letakkan telapak tangan di depan kaki dan kemudian tolak kedua kaki ke atas. Setelah menolak posisikan kaki agar rapat kemudian secara perlahan diluruskan sekaligus tangan dan bahu mengatur keseimbangan tubuh untuk tidak jatuh.

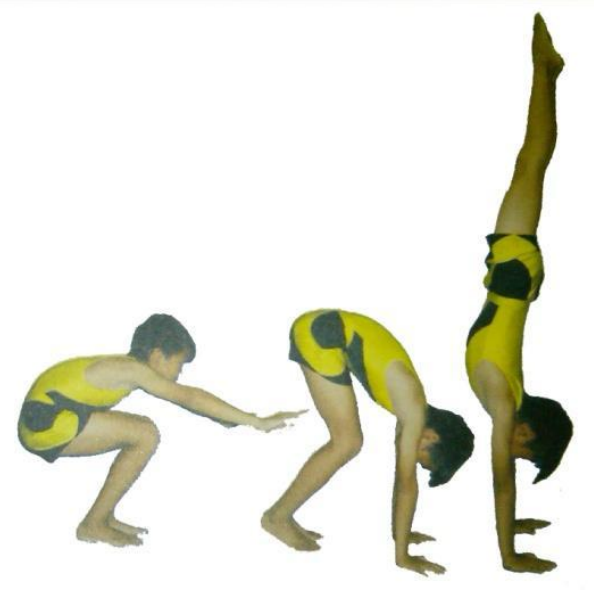

Gambar 1. Rangkaian keterampilan gerak handstand sikap awal jongkok (sumber: Biasworo Adisuyanto, 2009:101)

Sikap awal berdiri, dengan mengayunkan satu kaki; Keterampilan gerak handstand juga dapat diawali dari sikap berdiri. Posisi tangan di atas lurus dan kemudian diturunkan bersamaan dengan kaki kiri melangkah ke depan. Julurkan telapak tangan hingga ke bawah dan kaki kiri ditekuk. Dorong kaki kiri dan ayunkan kaki kanan hingga lurus ke atas, kemudian kaki kiri menyusul kaki kanan hingga rapat.
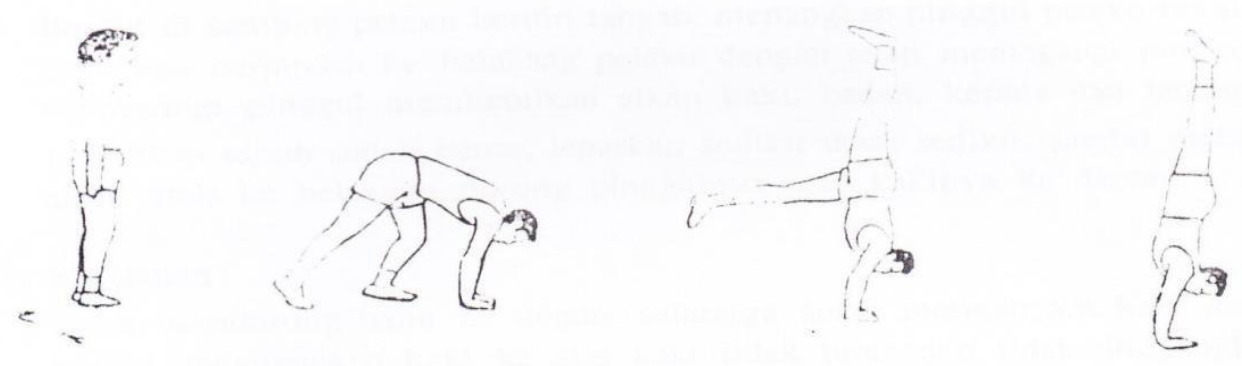

Gambar 2. Rangkaian keterampilan gerak handstand sikap awal berdiri dengan mengayunkan satu kaki

(sumber: Sumanto Y; Sukiyo , 1992 : 107) 
Sikap awal berdiri, dengan mengangkat dua kaki secara bersama-sama (kaki rapat); Keterampilan gerak dasar handstand dengan awalan mengangkat dua kaki secara bersama-sama sering dikenal dengan istilah (press to handstand). Gerakan ini lebih sulit dilakukan dari awalan yang sebelumnya karena membutuhkan kekuatan pergelangan tangan, tangan, bahu dan otot perut yang benar-benar kuat. Tanpa ditunjang dengan kekuatan empat komponen tersebut anak didik akan mengalami kesulitan dalam pelaksanaannya.

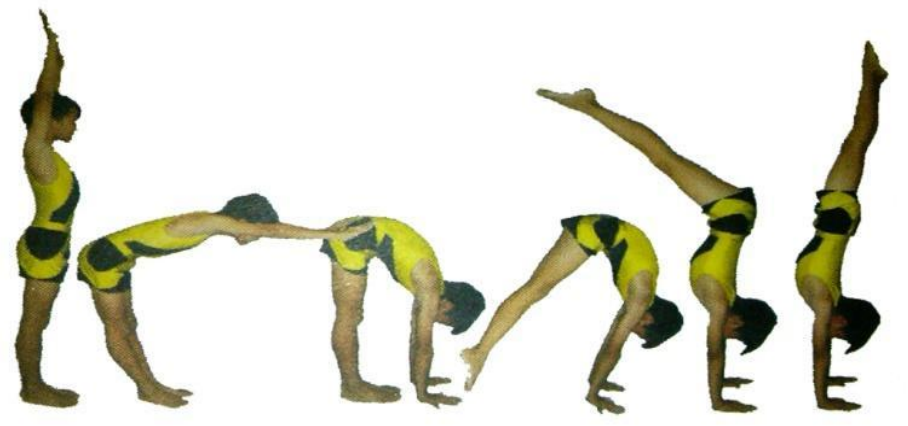

Gambar 3. Rangkaian keterampilan gerak handstand sikap awal berdiri dengan mengangkat dua kaki secara bersama-sama (kaki rapat) (sumber: Biasworo Adisuyanto, 2009:101)

Berguling ke belakang kaki lurus; Pelaksanaan gerak dasar handstand dari awalan roll belakang menyudut membutuhkan kekuatan otot lengan, bahu dan perut serta ketepatan mengatur keseimbangan badan saat melakukan gerak dasar handstand. diawali dari duduk kaki lurus, kemudian berguling ke belakang dengan posisi kaki tetap lurus. Letakkan tangan di samping kepala dengan ujung jari menghadap ke bahu. Ketika ujung kaki telah melampaui kepala, ayunkan kedua kaki secara bersama ke atas diiringi kedua tangan mendorong dengan kuat. Secara otomatis, badan terangkat ke atas. Ketika sudah lurus, kencangkan seluruh tubuh mulai dari tangan sampai dengan ujung kaki sehingga keseimbangan dapat diatasi dengan baik.

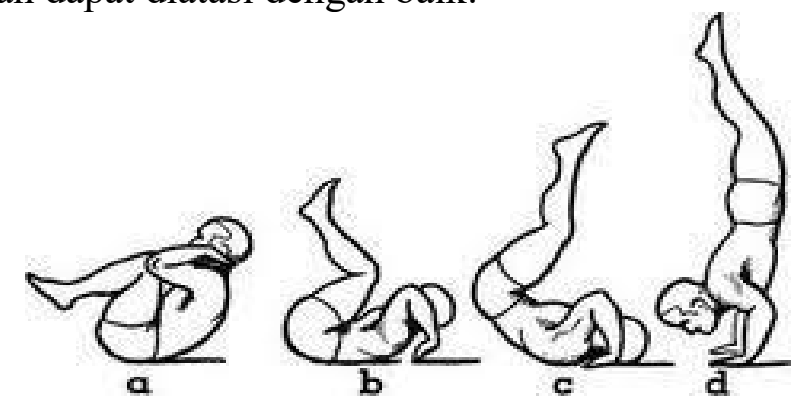

Gambar 4. Rangkaian keterampilan gerak handstand berguling ke belakang kaki lurus

Berkaitan dengan jenis rangkaian keterampilan gerak handstand yang telah dikemukakan di atas, jenis handstand yang akan dipraktikan dalam penelitian ini adalah handtsand sikap awal berdiri dengan mengayunkan satu kaki. Hal ini dikarenakan handtsand sikap awal berdiri dengan mengayunkan satu kaki lebih mudah 
gerakannya dibandingkan dengan ketrampilan gerak handstand dengan awalan yang lain. Selain itu, dalam pembelajaran di tingkat sekolah menengah lanjutan sebagai awal diajarkan handstand sikap awal berdiri dengan mengayunkan satu kaki. Akan tetapi, masih banyak dijumpai siswa yang belum bisa melakukan gerakan dengan baik. Dalam melakukan gerakan handstand ada beberapa kesalahan yang sering dilakukan oleh siswa, yaitu : 1) Letak kedua tangan dan kepala tida merupakan segitiga sama sisi, 2) Ketika meluruskan kaki ke atas tidak dibantu dengan mendorongkan pinggul ke depan secara perlahan, 3) Pada saat melakukan tangan masih membengkok, tidak sedikit juga yang tangannya gemetaran karena posisi tumpuan yang kurang benar.

Kesalahan-kesalahan tersebut di atas harus dihindari pada saat melakukan gerakan handstand. Salah satu upaya untuk menghindari kesalahan tersebut ialah dengan memberikan bantuan. Cara memberi pertolongan pada siswa yang mengalami kesulitan pada saat melakukan handstand adalah : 1) Berdiri disamping siswa yang akan melakukan.2) Bagi siswa yang kurang kuat dalam menolak, guru bersiap memegangi pinggul dan membantu menarik pinggul perlahan-lahan ke atas belakang pada saat siswa melakukan tolakan.3) Ketika siswa sudah bisa mengayunkan kaki ke atas, guru bersiap menangkap pergelangan kaki atau paha siswa. 4) Membantu meluruskan dan menjaga keseimbangan pada saat kaki berada di atas. Cara memberikan bantuan pada gerakan handstand sangat penting dipahami oleh seorang guru pendidikan jasmani maupun pembantu gerakan handstand. Pemberian bantuan handstand yang benar akan lebih mempermudah seseorang dalam melakukan handstand. Akan tetapi jika pemberian bantuan justru salah maka akan dapat menimbulkan rasa takut dan cidera pada siswa. Pada dasarnya berbagai awalan ketrampilan gerak melakukan handstand membutuhkan adanya kesinambungan gerak dan keseimbangan yang baik agar gerakan terlihat luwes. "Tiga faktor yang harus dipertimbangkan untuk mengerti keseimbangan tubuh manusia: titik berat tubuh, dasar tumpuan dan garis titik berat" (Agus Mahendra, 2000:79). Faktor kelentukan dan kekuatan otot juga mempengaruhi gerak rang kaian handstand. Orang yang memiliki kelentukan tubuh yang baik tentunya akan lebih indah dalam melakukan gerakan senam. Seperti yang dikemukakan Agus Mahendra (2000: 31-32) bahwa "kelentukan dalam senam berkaitan dengan 3 hal, yaitu: (1) jarak yang luas dari kelentukan penting untuk keindahan, irama dan keanggunan gerak. (2) banyak keterampilan senam memerlukan kelentukan derajat tinggi sebelum dapat ditampilkan. Misalnya, guling depan kangkang atau kaki lurus tidak mungkin dilakukan tanpa kelentukan yang baik. (3) kelentukan yang baik akan menurunkan kemungkinan terjadinya cedera dan memperbaiki kesehatan tubuh. Begitu pula siswa harus memiliki dasar kekuatan yang baik guna melakukan gerakan senam. Selain kelentukan dan keseimbangan, kekuatan juga merupakan faktor penunjang utama dalam melakukan gerakan senam. Pemilihan sampel populasi siswa sekolah menengah kejuruan menjadi alternatif bagi penulis. Dari segi usia yang tergolong remaja jelas akan memiliki kekuatan yang lebih baik dari pada anak usia sekolah dasar, karena pada masa remaja (puberitas) latihan kekuatan otot akan lebih produktif. Secara fisik mereka juga lebih siap karena siswa SMK lebih sering di lapangan dari pada siswa SMA yang cenderung melakukan pembelajaran di dalam kelas.

Dengan menggunakan media audio visual pembelajaran akan menjadi lebih menarik karena media audio visual dapat menyampaikan informasi yang dapat didengar (audio) dan 
dapat dilihat (visual), sehingga dapat mendiskripsikan suatu masalah, suatu konsep, suatu proses atau suatu prosedur yang bersifat abstrak dan tidak lengkap menjadi lengkap dan jelas (Soepartono, 2000:16). Dengan adanya media pembelajaran audio visual yang menampilkan rangkaian gerak handstand mulai dari awalan, sikap inti dan sikap akhir yang berupa tayangan rangkaian gerak secara keseluruhan tentunya siswa akan mempunyai landasan pengetahuan tentang gerak apa yang harus ia lakukan dari awal sampai selesai. Penggunaan media tidak hanya membuat proses pembelajaran lebih efisien, tetapi materi pelajaran dapat diserap lebih mendalam. Pemahaman siswa akan lebih baik lagi jika diperkaya dengan kegiatan melihat, menyentuh, merasakan atau mengalami melalui media

\section{Metode Penelitian}

Action research adalah nama yang diberikan kepada suatu aliran dalam penelitian pendidikan. Untuk membedakan dengan action research dalam bidang lain para peneliti pendidikan sering mengunakan istilah "classroom action research" atau "action research". Action research bertujuan untuk memecahkan masalah-masalah melalui penerapan langsung di kelas atau tempat kerja (Islac, 1994). Dalam penelitian pendidikan action research tidak hanya terbatas pada ruang kelas saja, melainkan di mana saja guru bekerja atau mengajar. Selain dalam bidang pendidikan, action research juga sering digunakan dalam bidang-bidang lain. Penelitian ini dilaksanakan melalui dua siklus masing-masing siklus terdiri dari empat kegiatan yaitu: (a) perencanaan, (b) pelaksanaan tindakan, (c) Observasi, Evaluasi, dan (d) Refleksi.

Penelitian ini merupakan penelitian tindakan kelasdengan subjek dalam penelitian ini adalah siswa kelas XI MM2 SMKN 1 Miri yang terdiri dari 36 peserta didik.Adapun obyek penelitian ini adalah media audio visual, hasil belajar peserta didik. Data-data dalam penelitian ini yang akan di kumpulkan bersumber dari sumber data primer yang diperoleh dari siswa melalui tes tertulis dan sumber data sekunder yang diperoleh dari hasil observasi dan refleksi. Teknik pengumpulan data dalam penelitian ini melalui Tes, Observasi dan Dokumentasi.Sedangkan alat pengumpul data dalam PTK ini meliputi Tes, Observasi dan Dokumentasi. Untuk menjamin validitas data dan pertanggungjawaban yang dapat dijadikan dasar yang kuat untuk menarik kesimpulan, maka yang digunakan untuk memeriksa validitas data yaitu, hasil belajar dengan validitas isi dan keaktifan dengan teknik trianggulasi. Dalam penelitian ini terdapat 3 macam data aktifitas belajar yaitu data kondisi awal, data siklus I dan data siklus II. Data hasil belajara berupa data kuantitatif yang diperoleh dari hasil tes kemudian diolah dengan mengunakan deskripsi pesentase.

Penelitian Tindakan kelas ini dilaksanakan dalam dua siklus yang masing-masing siklus terdiri dari 2 pertemuan dengan durasi waktu 2 x 40 menit tiap-tiap pertemuan. Adapun prosedur penelitian masing-masing siklus meliputi: perencanaan, pelaksanaan tindakan, observasi, evaluasi-refleksi. Tahapan tersebut merupakan suatu rangkaian yang berkelanjutan.

\section{Hasil Penelitian dan Pembahasan}

Nilai rata-rata untuk ranah afeksi dengan beberapa penilaian yang telah diamati selama pembelajaran berlangsung, menunjukkan penilaian berkomunikasi memperoleh rata-rata persentase sebanyak $87,61 \%$ memperhatikan penjelasan guru memperoleh rata-rata persentase sebanyak $77,14 \%$, aktif dalam pembelajaran memperoleh rata- 
rata sebanyak $78,57 \%$, disiplin memperoleh rata-rata sebanyak $71,42 \%$, dan percaya diri sebanyak 74,28\% sehingga rata-rata kelas mencapai 77,81\% (cukup baik). Nilai ratarata untuk ranah kognisi dengan beberapa pertanyaan yang berkaitan dengan pemahaman pembelajaran handstand yang telah diberikan pada siklus pertama, memperoleh rata-rata soal nomor 1 sebanyak $80 \%$, soal nomor 2 sebanyak $70 \%$, soal nomor 3 sebanyak $80 \%$, soal nomor 4 sebanyak 90\%, soal nomor 5 sebanyak 77\%, soal nomor 6 sebanyak 80\%, soal nomor 7 sebanyak $67 \%$, dan soal nomor 8 sebanyak $70 \%$, soal nomor 9 sebanyak $87 \%$, soal nomor 10 sebanyak $83 \%$, soal nomor 11 sebanyak $83 \%$, soal nomor 12 sebanyak $83 \%$, soal nomor 13 sebanyak $67 \%$, soal nomor 14 sebanyak $77 \%$ dan soal nomor 15 sebanyak $87 \%$ sehingga jumlah rata-rata pemahaman siswa terhadap pembelajaran handstand melalui kuesioner yang diberikan adalah 79\% (kualifikasi cukup).

Nilai rata-rata untuk ranah psikomotor dengan penilaian yang berkaitan dengan praktik handstand yang telah diberikan pada siklus pertama, menunjukkan penilaian sikap awal sebanyak 71\%, penilaian sikap inti sebanyak 58\%, penilaian sikap akhir 68\%, sehingga jumlah rata-rata praktik roll depan adalah 66\% (kurang baik). Setelah memasuki pembelajaran berikutnya terdapat perubahan sikap siswa dalam mengikuti pembelajaran. Banyak sebagian siswa yang antusias mengikuti pembelajaran setelah melihat tayangan video. Hal ini ditunjukan dalam pengamatan minat yang didapat peneliti melalui penyebaran angket yang berkaitan dengan minat dan motivasi siswa, yaitu angket no 16 sampai no20 dengan rincian sebagai berikut: rata-rata persentase soal no 16 sebanyak $100 \%$. Sesuai dengan pertanyaan angket, nilai tersebut menjelaskan bahwa seluruh siswa lebih senang pembelajaran dilakukan menggunakan media audio visual. Berikutnya persentase rata-rata soal no 17 sebanyak $87 \%$, no 18 sebanyak $20 \%$, no 19 sebanyak 90\% dan no 20 sebanyak 93\%. Sesuai dengan hasil prosentase tersebut, siswa akan lebih cepat mengerti dan memahami materi yang disajikan, selain iu siswa juga akan lebih termotifasi mengikuti pembelajaran. Hal ini terlihat dari nilai persentase angket no 17,19 dan 20 .

Berdasarkan hasil observasi yang dilakukan oleh peneliti dan kolabolator pada siklus pertama, rata-rata untuk nilai afeksi atau sikap siswa dalam pembelajaran handstand menggunakan media audio visual mencapai $77 \%$. Pemahaman yang dinilai dari pengisian kuesioner mencapai $79 \%$, dan nilai rata- rata kelas XI Multimedia 2 dalam praktik handsatand mencapai $66 \%$. Dilihat dari perolehan nilai rata-rata untuk afeksi masuk dalam kriteriacukup baik maka perlu adanya penekanan sehingga memperoleh hasil yang lebih baik lagi pada pembelajaran selanjutnya. Demikian pula dengan nilai rata-rata yang diperoleh dari pemahaman melalui kuesioner terutama pada soal nomor 7 (dengan kualifikasi kurang baik); yaitu tentang sikap kaki pada posisi handstand, dan butir soal nomor 13 (dengan kualifikasi kurang baik); yaitu tentang posisi jari-jari tangan pada saat melakukan gerakan handstand. Serupa dengan nilai rata-rata yang diperoleh siswa pada keterampilan praktik siswa. Secara keseluruhan, kesalahan - kesalahan yang sering dilakukan oleh siswa pada saat melakukan handstand adalah: 1) siswa masih banyak yang membuka lengan teralu lebar pada saat tangan menempel matras. 2) pandangan yang mengarah ke perut pada saat posisi sudah berdiri dengan kedua tangan. 3) posisi kaki yang belum rapat dan lurus pada saat handstand. Presentase skor tercapai pada siklus pertama ranah afeksi $77 \%$, kognisi $79 \%$, dan psikomotor $66 \%$ sehingga jumlah rata-rata nilai 
prosentase skor tercapai adalah $74 \%$ dengan total siswayang tuntas sebanyak 20 siswa, yang berarti $66 \%$ siswa yang tuntas. Dengan demikian berarti pembelajaran handstand dengan menggunakan media audio visual belum melampaui indikator ketercapaian ketuntasan belajar yaitu sebesar 75\%, sehingga peneliti harus melanjutkan ke siklus kedua untuk mencapai target indikator ketercapaian. Setelah dilakukan perbaikan pada siklus II memperoleh hasil persentase skor tercapai pada siklus II ranah afeksi $84 \%$, kognisi $87 \%$, dan psikomotor $86 \%$ sehingga jumlah rata-rata nilai prosentase skor tercapai adalah $85 \%$ dengan total siswayang tuntas sebanyak 26 siswa, yang berarti $86 \%$ siswa yang tuntas.

\section{Simpulan dan Saran}

Dari hasil penelitian dapat ditarik kesimpulan bahwa pembelajaran handstand menggunakan media audio visual dapat meningkatkan hasil belajar handstand siswa kelas XI Multimedia 2 SMK Negeri 1 Miri Kabupaten Sragen Semester 1 Tahun ajaran 2019/2020, hal tersebut dapat dilihat dari: 1) Sikap siswa dalam mengikuti pembelajaran handstand menggunakan media audio visual (afektif) pada siklus pertama mencapai tingkat pencapaian $77 \%$, sedangkan pada siklus kedua mencapai $84 \%$. Ini berarti ada peningkatan sebesar 0,3 (middle gain), 2)Pemahaman Siswa dalam Pembelajaran hanstand menggunakan media audio visual pada siklus pertama hanya 79\%, sedangkan pada siklus kedua mencapai85\%. Ini berarti ada kenaikan sebesar 0,28 (low gain), 3) Kemampuan praktik (psikomotor) siswa kelas XI Multimedia I SMK Negeri 1 Miri dalam melakukan handstand dalam mengikuti pembelajaran handstand menggunakan media audio visual pada siklus pertama mencapai $65 \%$, sedangkan pada siklus kedua mencapai $70 \%$, ini berarti ada peningkatan 0,14 (low gain), 4) Dari hasil data yang diperoleh melalui lembar pengamatan siswa (afektif), kuesioner (kognitif) dan lembar test praktik (psikomotor), penelitian tindakan kelas ini dinyatakan sudah mencapai ketuntasan klasikal sebesar $80 \%$ (berhasil), 5) Dari data hasil belajar siswa secara lasikal pada siklus pertama mencapai 73 dan pada siklus kedua mencapai 81 maka terdapat peningkatan hasil belajar sebesar 0,29 (low gain).

Dari hasil penelitian yang sudah dilakukan, ternyata siswa kelas XI Multimedia 2 lebih tertarik mengikuti pembelajaran handstand menggunakan media audio visual. Oleh karena itu, penulis mengharapkan pada guru penjas di SMK tersebut untuk dapat mengunakan hasil penelitian ini. Bagi rekan sejawat yang diluar mata pelajaran, dapat terinspirasi untuk memanfaatkan model pembelajaran sesuai dengan karakteristik mata pelajaran yang diampu. Harapannya semua guru dapat mengembangkan profesi dalam melaksanakan tugas utama sebagai guru yaitu mengajar.

\section{Daftar Rujukan}

Adang Suherman. (2000). Dasar-dasar Pendidikan Jasmani. Jakarta: Depdiknas. Agus Mahendra. (2000). Senam. Depdiknas. Direktorat Jendral PendidikanDasar dan Menengah Proyek Penataran Guru SLTP Setara D-III.

Amung Ma'mun. (2000). Perkembangan Gerak dan Belajar Gerak. Jakarta: Depdiknas. BiasworoAdisuyanto. (2009). Cerdas dan Bugar dengan Senam Lantai. Jakarta: PT Gramedia Widiasarana Indonesia.

Dimyati, Mudjiono. (2009). Belajar dan Pembelajaran. Jakarta: RinekaCipta. 
Halidin, dkk.(2014). Upaya Meningkatkan Minat Mengikuti Pembelajaran Penjaskes Dengan Metode Bermain (Studi Kasus Kelas V Mis Al Ma'arif 02 Tanjung Sari Kecamatan Nanga Pinoh). Jurnal Pendidikan Jasmani Kesehatan dan Rekreasi, Volume 1(1), Juli 2014, Hal: 28-32.

Indrawani. (2019). Meningkatkan Keterampilan Permainan Sepakbola Menggunakan Metode Pembelajaran Demonstrasi Pada Siswa Kelas VI S DN 003 Pulau Kopung Sentajo Kecamatan Sentajo Raya. Jurnal PAJAR (Pendidikan dan Pengajaran), Volume 3(3) Mei 2019

Samsudin. (2008). Pembelajaran Pendidikan Jasmani Olahraga dan Kesehatan. Jakarta: Prenadamedia Group.

Soepartono. (2000). Media Pembelajaran. Depdiknas.

Sugiyanto, Sudjarwo. (1993). Perkembangan dan Belajar Gerak. Jakarta: Depdiknas. Sumanto Y., Sukiyo. (1992). Senam. Departemen Pendidikan dan Kebudayaan Direktorat Jenderal Pendidikan Tinggi. 